\title{
Workers' Health in Brazil: Accidents recorded by Social Security from 2008 to 2014
}

\author{
A Saúde do Trabalhador no Brasil: Acidentes registrados pela Previdência Social de 2008 a 2014 \\ La Salud del Trabajador en Brasil: Accidentes registrados por el Seguro Social de 2008 a 2014
}

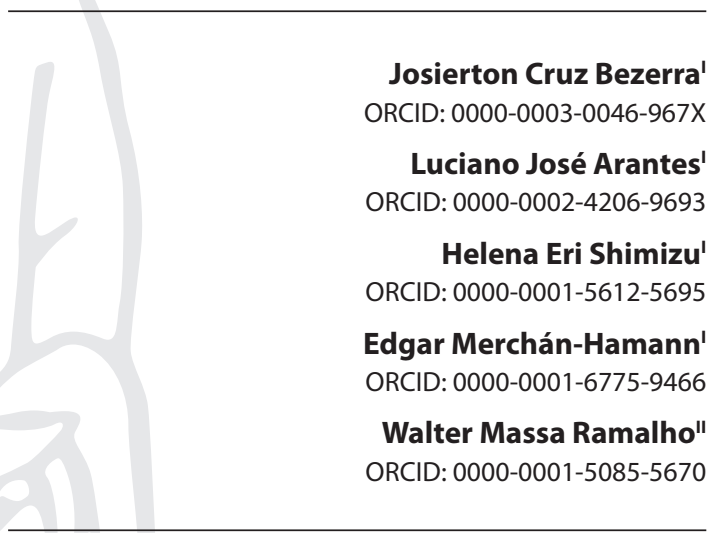

'Universidade de Brasília. Brasília, Distrito Federal, Brazil. "Universidade de Brasília. Ceilândia, Distrito Federal, Brazil.

How to cite this article:

Bezerra JC, Arantes LJ, Shimizu HE, Merchán-Hamann E,

Ramalho WM. Workers' Health in Brazil: Accidents recorded by Social Security from 2008 to 2014. Rev Bras Enferm. 2020;73(6):e20180892. doi: http://dx.doi.org/10.1590/0034-7167-2018-0892

Corresponding author:

Josierton Cruz Bezerra

E-mail: josierton@gmail.com

EDITOR IN CHIEF: Antonio José de Almeida Filho ASSOCIATE EDITOR: Rafael Silva

Submission: 03-17-2019

Approval: 07-31-2019

\begin{abstract}
Objectives: to analyze the incidence of occupational accidents in Brazil, recorded by Social Security according to the geographic regions, age group, gender and their prevalence according to the causes and branch of economic activity. Methods: ecological descriptive study with time series analysis from 2008 to 2014. Data on the beginning and end of the historical series were compared in each ecological unit studied. Results: the South and Southeast regions, male, between 20 and 49 years of age presented the highest falls in incidence. $70.87 \%$ of the causes occurred in group XIX of ICD-10. The economic activity with the highest prevalence of accidents was the manufacturing industry. Conclusions: accidents at work have decreased in Brazil, however, the incidence is still high. Advances need to be made in the recording of accidents and in the prevention and surveillance of workers' health. Descriptors: Occupational Accidents; Occupational Health; Social Security; Workflow; Accident Prevention.
\end{abstract}

\section{RESUMO}

Objetivos: analisar a incidência dos acidentes de trabalho no Brasil registrados pela Previdência Social, segundo as regiões geográficas, faixa etária, sexo e sua prevalência, de acordo com as causas e o ramo de atividade econômica. Métodos: estudo descritivo ecológico, com análise de série temporal no período de 2008 a 2014. Os dados do início e do final da série histórica foram comparados em cada unidade ecológica estudada. Resultados: as regiões Sul e Sudeste, o sexo masculino, a faixa etária entre 20 e 49 anos apresentaram as maiores quedas das incidências. 70,87\% das causas ocorreram no grupo XIX da CID-10. A atividade econômica com maior prevalência de acidentes foi a indústria de transformação. Conclusões: os acidentes de trabalho diminuíram no Brasil, mas sua incidência ainda é alta. São necessários avanços no registro dos acidentes e nas ações de prevenção e vigilância à saúde do trabalhador.

Descritores: Acidentes de Trabalho; Saúde do Trabalhador; Fluxo de Trabalho; Previdência Social; Prevenção de Acidentes.

\section{RESUMEN}

Objetivos: analizar la incidencia de los accidentes de trabajo en Brasil, registrados por la Seguro Social, según las regiones geográficas, grupo de edad, sexo y su prevalencia de acuerdo con las causas y rama de actividad económica. Métodos: estudio descriptivo ecológico con análisis de serie temporal en el período de 2008 a 2014. Los datos del inicio y del final de la serie histórica se compararon en cada unidad ecológica estudiada. Resultados: las regiones Sur y Sudeste, el sexo masculino, el grupo de edad entre 20 y 49 años presentaron las mayores caídas de las incidencias. El 70,87\% de las causas ocurrieron en el grupo XIX de la CID-10. La actividad económica con mayor prevalencia de accidentes fue la industria de transformación. Conclusiones: los accidentes de trabajo disminuyeron en Brasil, sin embargo, la incidencia aún es alta. Se necesitan avances en el registro de los accidentes y en las acciones de prevención y de vigilancia a la salud del trabajador. Descriptores: Accidentes de Trabajo; Salud Laboral; Seguridad Social; Flujo de Trabajo, Prevención de Accidentes. 


\section{INTRODUCTION}

According to the International Labor Organization, global accident costs account for $4 \%$ of the world's gross domestic product (GDP). In developing countries, these numbers reach $10 \%$ of $\mathrm{GDP}^{(1)}$. In Brazil, due to the high incidence of occupational accidents, the National Institute of National Insurance (INSS), from 2008 to 2014, through the granting of social security benefits, paid an average of R\$ 704 million to its secured workers ${ }^{(2)}$. Such resources could be used in other social policies.

The main characteristic of the work accident is the commitment of the workers' health caused by the activity in which it operates. Deaths can range from $18 \%$ of deaths in low-and middle-income countries to $5 \%$ in high-income countries ${ }^{(3)}$. In addition, unaccountable costs related to accidents resulting from the suffering of such accidents should also be considered ${ }^{(4)}$.

It is estimated that the true number of occupational accidents is higher than those registered by government agencies in Brazil. This under-reporting contributes to an inappropriate analysis of such accidents ${ }^{(5)}$.

In Brazil, given the need and complexity of actions related to workers' health, several government sectors have made efforts to work in an articulated way, however weaknesses in the adequate protection of workers' health are still observed.

The federal government has a fundamental role in assessing the risks to which the worker is exposed, but the inspections occur, after the occurrence of damage to the health of the worker and assume, exclusively, the punitive role ${ }^{(6)}$.

In recent decades, Social Security has been trying to reduce the high costs borne by the State to sick workers ${ }^{(7)}$. However, there are few studies that investigate the behavior of work accidents, including those caused by health services work, covering the entire Brazilian territory under the care of Social Security, of great importance for the monitoring of policies and actions in that scope.

Thus, it is important to broaden the knowledge on the subject, contributing to the reflection of managers, workers and health/ nursing professionals, aiming at the implementation of preventive measures to protect workers' health.

\section{OBJECTIVES}

To analyze the incidence of occupational accidents in Brazil, according to geographic regions, age group and sex; and the prevalence of these work accidents according to causes and economic activities in the period between 2008 and 2014, in the workers enrolled in Social Security.

\section{METHODS}

\section{Ethical aspects}

According to Resolution No. 510/2016 of the National Health Council, since it is a research that uses information from databases of public access under the terms of Law 12,527, whose information is aggregated without possibility of individual identification, this study was not registered in the system for Research Ethics
Committee (REC)/ National Commission of Ethics in Research (CONEP).

\section{Study design, location, period and sample}

A descriptive ecological study, time series was carried out from 2008 to 2014 in Brazil with workers linked to Social Security.

\section{Study protocol}

Using data registered in the Social Security platform and its statistical yearbooks available at www.previdencia.gov.br/dadosabertos/, collected on 10/6/16.

The data presented was copied and transferred to Excel ${ }^{\circ}$ spreadsheets. In this software the incidence of work accidents was calculated as the number of new cases registered by Social Security, divided by the number of workers linked to Social Security in the place and year, multiplied by 1000 workers. The numerator data were taken from the Social Security online platform and, for the denominator, the publication of the Ministry of Social Security that presents the annual consolidated figures from 2003 to $2014^{(7)}$.

Incidences were calculated for the whole country, for the large regions, for both sexes and according to age groups (up to 19 years, 20 to 49 years, 50 to 64 years and from 65 years and over). The data ignored in each of these classifications were not considered in the study.

The prevalence of accidents in the period between 2008 and 2014 was estimated according to the chapters presented by the International Statistical Classification of Diseases and Related Health Problems (ICD-10) for the causes of occupational accidents and the divisions of the National Classification of Diseases Economic Activities (CNAE 2.0) in the main branches of activity.

The ICD-10 chapters defined for the study were those with the highest prevalence of causes. The groups, according to economic activities, were defined for the study because they also present more records of occupational accidents.

The prevalence was calculated by dividing the number of work accidents registered by Social Security in each of the subgroups of ICD-10 and CNAE 2.0 defined for this study, divided by the total number of work accidents registered by Social Security in the period studied, multiplied by 100 .

\section{RESULTS}

In Brazil, more than 700 thousand accidents per year were identified by Social Security in the period from 2008 to 2014, as can be seen in Table 1. However, the incidence decreased by $29.69 \%$ in this period, varying from 14.01 to 9.85 , when comparing the data for 2008 and 2014 (Table 2).

The South and Southeast regions had the highest incidences with 17.96 and 14.28 in 2008 and decreased to 12.44 and 10.16, reaching reductions of $30.71 \%$ and $28.82 \%$, respectively. The Center-West region showed the greatest reduction in incidence, ranging from 12.42 to 8.31 , that is, a reduction of $31.31 \%$. The North region showed the lowest variation, going from 12.40 to 9.12 , with a fall of $26.47 \%$ (Table 2 ). 
Table 1 - Distribution of occupational accidents and workers registered in Social Security in Brazil according to sex, geographical regions and age group, 2008 to 2014 (5,070,653 accidents)

\begin{tabular}{|c|c|c|c|c|c|c|c|c|}
\hline Ecological Units & & 2008 & 2009 & 2010 & 2011 & 2012 & 2013 & 2014 \\
\hline Brazil & Accidents & 755,854 & 733,265 & 709,340 & 720,509 & 713,889 & 725,589 & 712,207 \\
\hline & Workers & $53,964,928$ & $55,877,835$ & $60,197,924$ & $64,292,255$ & $67,246,063$ & $69,837,123$ & $71,493,806$ \\
\hline \multicolumn{9}{|l|}{ Gender } \\
\hline \multirow[t]{2}{*}{ Male } & Accidents & 549,832 & 527,851 & 508,285 & 510,528 & 501,035 & 500,071 & 484,391 \\
\hline & Workers & $30,759,230$ & $31,404,280$ & $33,332,706$ & $35,200,587$ & $36,607,382$ & $38,253,184$ & $38,495,865$ \\
\hline \multirow[t]{2}{*}{ Female } & Accidents & 206,022 & 205,414 & 201,055 & 209,981 & 212,854 & 225,518 & 227,816 \\
\hline & Workers & $21,906,908$ & $22,922,107$ & $24,656,781$ & $26,685,449$ & $28,658,514$ & $30,822,253$ & $30,352,418$ \\
\hline \multicolumn{9}{|l|}{ Region } \\
\hline \multirow[t]{2}{*}{ South } & Accidents & 172,187 & 166,408 & 158,449 & 155,461 & 150,548 & 159,261 & 158,966 \\
\hline & Workers & $9,590,076$ & $9,965,741$ & $10,632,848$ & $11,283,605$ & $11,715,548$ & $12,201,054$ & $12,646,690$ \\
\hline \multirow[t]{2}{*}{ Southeast } & Accidents & 415,013 & 392,393 & 382,154 & 391,279 & 390,961 & 394,678 & 382,984 \\
\hline & Workers & $29,072,532$ & $30,061,006$ & $32,130,617$ & $34,175,703$ & $35,497,860$ & $36,688,665$ & $37,333,834$ \\
\hline \multirow[t]{2}{*}{ Middle-west } & Accidents & 52,439 & 51,312 & 47,712 & 48,317 & 49,550 & 51,786 & 50,366 \\
\hline & Workers & $4,184,814$ & $4,406,813$ & $4,789,310$ & $5,164,176$ & $5,457,216$ & $5,683,942$ & $5,903,647$ \\
\hline \multirow[t]{2}{*}{ Northeast } & Accidents & 85,931 & 92,132 & 91,269 & 93,686 & 90,572 & 88,014 & 87,526 \\
\hline & Workers & $8,282,576$ & $8,820,354$ & $9,753,241$ & $10,532,912$ & $11,230,274$ & $11,744,452$ & $12,077,360$ \\
\hline \multirow[t]{2}{*}{ North } & Accidents & 30,290 & 31,020 & 29,756 & 31,766 & 32,262 & 31,850 & 31,832 \\
\hline & Workers & $2,442,803$ & $2,545,181$ & $2,807,684$ & $3,044,201$ & $3,260,326$ & $3,410,205$ & $3,428,299$ \\
\hline \multicolumn{9}{|l|}{ Age range } \\
\hline \multicolumn{9}{|l|}{ Up to 19 years } \\
\hline \multirow[t]{2}{*}{ Male } & Accidents & 21,504 & 17,763 & 18,378 & 19,154 & 18,939 & 19,057 & 17,762 \\
\hline & Workers & $1,309,481$ & $1,201,193$ & $1,283,648$ & $1,495,965$ & $1,718,304$ & $1,811,369$ & $1,682,729$ \\
\hline \multirow[t]{2}{*}{ Female } & Accidents & 4,832 & 4,396 & 4,593 & 4,890 & 4,850 & 5,501 & 5,478 \\
\hline & Workers & 920,677 & 871,620 & 945,002 & $1,114,894$ & $1,326,898$ & $1,438,277$ & $1,273,936$ \\
\hline \multicolumn{9}{|l|}{20 to 49 years } \\
\hline \multirow[t]{2}{*}{ Male } & Accidents & 464,874 & 444,307 & 426,460 & 425,281 & 415,331 & 412,252 & 397,990 \\
\hline & Workers & $24,873,938$ & $25,316,728$ & $26,718,519$ & $27,968,378$ & $28,674,808$ & $29,800,139$ & $29,812,336$ \\
\hline \multirow[t]{2}{*}{ Female } & Accidents & 175,050 & 173,935 & 170,011 & 176,803 & 178,984 & 187,940 & 189,126 \\
\hline & Workers & $17,843,70$ & $18,600,209$ & $19,895,160$ & $21,414,248$ & $22,587,141$ & $24,167,438$ & $23,596,333$ \\
\hline \multicolumn{9}{|l|}{50 to 64 years } \\
\hline \multirow[t]{2}{*}{ Male } & Accidents & 61,868 & 64,069 & 61,775 & 64,175 & 64,720 & 66,493 & 66,043 \\
\hline & Workers & $4,154,032$ & $4,446,529$ & $4,859,764$ & $5,271,383$ & $5,642,046$ & $6,011,905$ & $6,318,730$ \\
\hline \multirow[t]{2}{*}{ Female } & Accidents & 25,671 & 26,560 & 25,960 & 27,706 & 28,459 & 31,325 & 32,436 \\
\hline & Workers & $2,927,272$ & $3,221,340$ & $3,571,709$ & $3,994,972$ & $4,437,955$ & $4,873,023$ & $5,099,324$ \\
\hline \multicolumn{9}{|l|}{65 years or more } \\
\hline \multirow[t]{2}{*}{ Male } & Accidents & 1,586 & 1,712 & 1,672 & 1,918 & 2,045 & 2,269 & 2,596 \\
\hline & Workers & 396,045 & 417,305 & 450,633 & 498,819 & 556,814 & 616,514 & 668,790 \\
\hline \multirow[t]{2}{*}{ Female } & Accidents & 469 & 523 & 491 & 582 & 561 & 752 & 776 \\
\hline & Workers & 200,712 & 216,829 & 234,535 & 264,988 & 298,956 & 337,296 & 365,481 \\
\hline
\end{tabular}

Source: Statistical Yearbook of Social Security.

Table 2 - Distribution of the incidence of occupational accidents in Brazil (per 1000) registered in Social Security according to geographic regions, sex and age group, 2008 to 2014

\begin{tabular}{|c|c|c|c|c|c|c|c|c|c|}
\hline Ecological Units & & 2008 & 2009 & 2010 & 2011 & 2012 & 2013 & 2014 & $\%$ of reduction \\
\hline Brazil & & 14.01 & 13.12 & 11.78 & 11.20 & 10.61 & 10.39 & 9.85 & 29.69 \\
\hline \multicolumn{10}{|l|}{ Regions } \\
\hline South & & 17.96 & 16.70 & 14.89 & 13.63 & 12.85 & 13.08 & 12.44 & 30.71 \\
\hline Southeast & & 14.28 & 13.05 & 11.89 & 11.30 & 11.01 & 10.79 & 10.16 & 28.82 \\
\hline Middle-west & & 12.42 & 11.65 & 9.95 & 9.31 & 9.08 & 9.13 & 8.53 & 31.31 \\
\hline Northeast & & 10.12 & 10.45 & 9.35 & 8.71 & 8.07 & 7.52 & 7.10 & 29.86 \\
\hline North & & 12.40 & 12.19 & 10.66 & 10.20 & 9.90 & 9.36 & 9.12 & 26.47 \\
\hline \multicolumn{10}{|l|}{ Gender } \\
\hline Male & & 17.88 & 16.81 & 15.20 & 14.32 & 13.65 & 13.07 & 12.44 & 30.42 \\
\hline Female & & 9.41 & 8.96 & 8.11 & 7.76 & 7.40 & 7.32 & 7.42 & 21.12 \\
\hline \multicolumn{10}{|l|}{ Age range } \\
\hline \multirow[t]{3}{*}{ Up to 19 years old } & Male & 16.42 & 14.79 & 13.63 & 12.70 & 10.93 & 10.52 & 10.93 & 33.46 \\
\hline & Female & 5.25 & 5.04 & 4.59 & 4.36 & 3.62 & 3.82 & 4.27 & 18.56 \\
\hline & Total & 11.76 & 10.69 & 9.78 & 9.06 & 7.73 & 7.55 & 7.64 & 35.06 \\
\hline \multirow[t]{3}{*}{ From 20 to 49 years old } & Male & 18.69 & 17.55 & 15.94 & 15.06 & 14.44 & 13.83 & 13.21 & 29.30 \\
\hline & Female & 9.81 & 9.35 & 8.51 & 8.19 & 7.89 & 7.78 & 7.93 & 19.20 \\
\hline & Total & 14.95 & 14.07 & 12.76 & 12.07 & 11.54 & 11.11 & 10.69 & 28.54 \\
\hline \multirow[t]{3}{*}{ From 50 to 64 years old } & Male & 14.89 & 14.41 & 12.71 & 11.86 & 11.46 & 11.06 & 10.25 & 31.20 \\
\hline & Female & 8.77 & 8.25 & 7.26 & 6.80 & 6.40 & 6.43 & 6.26 & 28.59 \\
\hline & Total & 12.35 & 11.82 & 10.40 & 9.67 & 9.23 & 8.98 & 8.38 & 32.14 \\
\hline \multirow[t]{3}{*}{65 years and over } & Male & 4.00 & 4.10 & 3.71 & 3.78 & 3.67 & 3.68 & 3.82 & 4.53 \\
\hline & Female & 2.34 & 2.41 & 2.09 & 2.17 & 1.87 & 2.23 & 2.08 & 10.77 \\
\hline & Total & 3.44 & 3.52 & 3.15 & 3.22 & 3.04 & 3.17 & 3.19 & 7.28 \\
\hline
\end{tabular}


There was a decrease in the incidence of accidents, regardless of the sex of the worker. This incidence is approximately double in males, however, the decrease in incidence is more significant in males than in females. For males, it decreased $30.42 \%$, ranging from 17.88 to 12.44 , while for females, the decrease was $21.12 \%$, ranging from 9.41 to 7.42 (Table 1 ).

In all the studied age groups, there was a decrease in the incidence of accidents. The highest incidence was found among workers between the ages of 20 and 49 in both sexes. In this group, the incidence decreased $28.54 \%$, with a decrease from 14.95 to 10.69. When we studied only males for this age group, it decreased by $29.30 \%$, from 18.69 to 13.21 . In females, it decreased $19.20 \%$, varying from 9.81 to 7.93 . The lowest incidence of accidents occurred after the age 65 , with a reduction of $7.28 \%$, ranging from 3.44 to 3.19. In this age group, the female sex presented a decrease of $10.77 \%$, ranging from 2.34 to 2.08 , while in the male sex, $4.53 \%$, ranging from 4.00 to 3.82 , characterizing the lower incidence variation in both sexes (Table 2). The five largest causes of absolute number of accidents in the analyzed period were injuries, fractures and hand and wrist trauma, dorsalgia, dislocation, sprain and distension of the joints and ligaments at the ankle and foot level (Table 3).

Approximately $71 \%$ of the causes of accidents at work, according to Social Security, cover the group of injuries, poisoning and some other consequences of external causes, especially wounds and fractures at the wrist and hands level. The problems located in the wrists and hands are predominant and stand out as the ones with the highest frequency in the general scenario (Table 3).

About $16 \%$ of the causes of work-related accidents to diseases of the musculoskeletal system and connective tissue, especially dorsalgia (Table 3). At a lower level of prevalence, reaching almost $3 \%$ of the causes, are the pathologies that correspond to external causes of morbidity and mortality. In this group, the most notable were accidents caused by bite or blow caused by dogs and accidents related to the provision of medical and surgical care (Table 3 ).

Mental and behavioral disorders reached $2.42 \%$ of the cases, most of accidents resulting from reactions to severe stress and adaptation disorders (Table 3 ). In the group related to factors influencing health status and contact with health services, $2.19 \%$ of work accidents were identified, with contact and exposure to communicable diseases being the most frequent (Table 3). Attaining a percentage of a little over $1 \%$, are diseases of the nervous system, and mononeuropathies of the upper limbs were the causes of higher prevalence (Table 3).

In relation to economic activities, the manufacturing industry accounted for approximately $32 \%$ of work-related accidents. In this branch, the raw sugar manufacturing and slaughtering activities of pigs, poultry and other small animals were highlighted (Table 4).

Table 3 - Main causes of occupational accidents in Brazil, recorded in Social Security, according to ICD-10, 2008 to 2014

\begin{tabular}{|c|c|c|c|c|c|}
\hline Disease Groups & $\mathbf{N}$ & $\%$ & Accident Cause & $\mathbf{N}$ & $\begin{array}{c}\% \\
\text { in cause } \\
\text { groups }\end{array}$ \\
\hline $\begin{array}{l}\text { Injuries, } \\
\text { poisonings and } \\
\text { some other } \\
\text { consequences of } \\
\text { external causes }\end{array}$ & $3,594,403$ & 70.87 & $\begin{array}{l}\text { Hand and wrist Injury } \\
\text { Fracture at wrist and hand level } \\
\text { Superficial trauma of the wrist and hand } \\
\text { Dislocation, sprain and distension of the joints and ligaments at the ankle and foot level } \\
\text { Leg fracture including ankle }\end{array}$ & $\begin{array}{l}511,092 \\
344,369 \\
241,080 \\
196,032 \\
168,715\end{array}$ & $\begin{array}{l}14.22 \\
9.58 \\
6.71 \\
5.45 \\
4.69\end{array}$ \\
\hline $\begin{array}{l}\text { Osteomuscular } \\
\text { and connective } \\
\text { tissue diseases }\end{array}$ & 816,170 & 16.09 & $\begin{array}{l}\text { Dorsalgia } \\
\text { Shoulder injuries } \\
\text { Synovitis and tenosynovitis } \\
\text { Other disorders of intervertebral discs } \\
\text { Other joint disorders not elsewhere classified }\end{array}$ & $\begin{array}{l}287,647 \\
150,620 \\
111,232 \\
47,620 \\
43,358\end{array}$ & $\begin{array}{l}35.24 \\
18.45 \\
13.63 \\
5.83 \\
5.31\end{array}$ \\
\hline $\begin{array}{l}\text { External causes } \\
\text { of morbidity and } \\
\text { mortality }\end{array}$ & 142,633 & 2.81 & $\begin{array}{l}\text { Dog Bite or Blow } \\
\text { Accidental cutting, puncture, perforation or bleeding during medical or surgical care } \\
\text { Accident not specified during the provision of medical and surgical care } \\
\text { Contact with sharp or penetrating object, undetermined intent } \\
\text { Aggression by sharp or penetrating object }\end{array}$ & $\begin{array}{l}11,227 \\
8,595 \\
6,138 \\
5,801 \\
5,231\end{array}$ & $\begin{array}{c}7.87 \\
6.03 \\
4.3 \\
4.07 \\
3.67\end{array}$ \\
\hline $\begin{array}{l}\text { Mental and } \\
\text { behavioral } \\
\text { disorders }\end{array}$ & 122,739 & 2.42 & $\begin{array}{l}\text { Reactions to severe stress and adaptation disorders } \\
\text { Depressive episodes } \\
\text { Other anxious disorders } \\
\text { Recurrent depressive disorder } \\
\text { Bipolar affective disorder }\end{array}$ & $\begin{array}{c}52,351 \\
29,464 \\
18,535 \\
7,592 \\
3,567\end{array}$ & $\begin{array}{r}42.65 \\
24.01 \\
15.1 \\
6.19 \\
2.91\end{array}$ \\
\hline $\begin{array}{l}\text { Factors } \\
\text { influencing } \\
\text { health status } \\
\text { and contact with } \\
\text { health services }\end{array}$ & 111,015 & 2.19 & $\begin{array}{l}\text { Contact with and exposure to communicable diseases } \\
\text { Occupational Exposure to Risk Factors } \\
\text { Examination and observation for other reasons } \\
\text { Problems related to other psychosocial circumstances } \\
\text { General examination and investigation of people with no reported complaints or diagnoses }\end{array}$ & $\begin{array}{l}51,831 \\
17,341 \\
10,142 \\
9,582 \\
6,004\end{array}$ & $\begin{array}{l}46.69 \\
15.62 \\
9.14 \\
8.63 \\
5.41\end{array}$ \\
\hline $\begin{array}{l}\text { Diseases of the } \\
\text { nervous system }\end{array}$ & 56,322 & 1.11 & $\begin{array}{l}\text { Mononeuropathies of the upper limbs } \\
\text { Epilepsy } \\
\text { Root and nerve plexus disorders } \\
\text { Mononeuropathies of lower limbs } \\
\text { Compressions of roots and nerve plexuses in diseases classified elsewhere }\end{array}$ & $\begin{array}{l}48,638 \\
1,150 \\
1,097 \\
854 \\
613\end{array}$ & $\begin{array}{l}86.36 \\
2.04 \\
1.95 \\
1.52 \\
1.09\end{array}$ \\
\hline
\end{tabular}


Table 4 - Distribution of work accidents in Brazil, recorded in Social Security, according to the main economic activities of the CNAE 2.0, 2008 to 2014

\begin{tabular}{|c|c|c|c|c|c|}
\hline $\begin{array}{l}\text { Branch of } \\
\text { activity }\end{array}$ & $\mathbf{N}$ & $\%$ & Most occupations & $\mathbf{N}$ & $\begin{array}{c}\% \\
\text { in the brach } \\
\text { activity }\end{array}$ \\
\hline $\begin{array}{l}\text { Manufacturing } \\
\text { Industries }\end{array}$ & $1,608,645$ & 31.72 & $\begin{array}{l}\text { Manufacture of raw sugar } \\
\text { Slaughter of Pigs, Poultry other small animals } \\
\text { Manufacture of parts and accessories for motor vehicles } \\
\text { Slaughter Reses, except Pigs } \\
\text { Manufacture of wearing apparel except underwear }\end{array}$ & $\begin{array}{l}108,485 \\
80,445 \\
51,646 \\
47,118 \\
46,778\end{array}$ & $\begin{array}{c}6.74 \\
5.0 \\
3.21 \\
2.93 \\
2.91\end{array}$ \\
\hline $\begin{array}{l}\text { Trade, repair } \\
\text { of motor } \\
\text { vehicles and } \\
\text { motorcycles }\end{array}$ & 667,936 & 13.17 & $\begin{array}{l}\text { Retail sale of merchandise, hypermarkets and supermarkets } \\
\text { Retail Hardware store, Wood and building material } \\
\text { Trade in Parts and Accessories for Motor Vehicles } \\
\text { Retail Sale of Other New Products } \\
\text { Wholesaler of beverages }\end{array}$ & $\begin{array}{c}150,435 \\
55,042 \\
35,841 \\
25,904 \\
23,947\end{array}$ & $\begin{array}{l}22.52 \\
8.24 \\
5.37 \\
3.88 \\
3.59\end{array}$ \\
\hline $\begin{array}{l}\text { Human health } \\
\text { and social } \\
\text { services }\end{array}$ & 441,638 & 8.71 & $\begin{array}{l}\text { Hospital Care Activities } \\
\text { Complementary Services Activities } \\
\text { Ambulatory Care Activities Performed by Doctors and Dentists } \\
\text { Unspecified human health care activities } \\
\text { Social work services without accommodation }\end{array}$ & $\begin{array}{c}359,956 \\
22,137 \\
15,632 \\
13,844 \\
12,023\end{array}$ & $\begin{array}{l}81.5 \\
5.01 \\
3.54 \\
3.13 \\
2.72\end{array}$ \\
\hline Construction & 402,066 & 7.93 & $\begin{array}{l}\text { Building Construction } \\
\text { Works for the Generation and Distribution of Electricity and for Telecommunications } \\
\text { Construction of Highways and Railways } \\
\text { Non-Specific Civil Engineering Works } \\
\text { Incorporation of Real Estate Developments }\end{array}$ & $\begin{array}{c}141,353 \\
41,409 \\
38,781 \\
28,145 \\
25,271\end{array}$ & $\begin{array}{l}35.17 \\
10.3 \\
9.64 \\
7.0 \\
6.28\end{array}$ \\
\hline $\begin{array}{l}\text { Transport, } \\
\text { storage and } \\
\text { mail }\end{array}$ & 370,058 & 7.3 & $\begin{array}{l}\text { Road Freight Transport } \\
\text { Mail Activities } \\
\text { Collective road transport of passengers, with fixed itinerary, municipal and metropolitan region } \\
\text { Storage } \\
\text { Collective road transport of passengers, with fixed itinerary, intermunicipal, interstate } \\
\text { and international }\end{array}$ & $\begin{array}{l}115,971 \\
85,048 \\
52,465 \\
13,832 \\
13,480\end{array}$ & $\begin{array}{l}31.34 \\
22.99 \\
14.18 \\
3.74 \\
3.64\end{array}$ \\
\hline
\end{tabular}

In activities related to trade, repair of motor vehicles and motorcycles, $13.17 \%$ of the cases occurred, with a higher prevalence in the retail trade of goods, hypermarkets and supermarkets (Table 4).

The prevalence of occupational accidents in the field of human health and social services was around $9 \%$. In this group, those activities related to hospital care had the highest prevalence of accidents and the highest number of cases in relation to all occupations analyzed (Table 4).

The construction activity segment corresponded to $7.93 \%$ of the cases, with a higher prevalence in the construction activity of buildings (Table 4). In the transport, warehousing and mail sectors, $7.3 \%$ of the accidents were found, with emphasis on the activity of road freight transport (Table 4).

\section{DISCUSSION}

Despite the fact that this study presents a large number of work-related accidents, it has been observed a reduction in its incidence in Brazil, according to geographic regions, sex and age, demonstrating similarity with studies described in the Brazilian literature ${ }^{(8-9)}$. Factors such as better working conditions stimulated by public policies that encourage investment in accident prevention, expansion of the service sector, causing workers to migrate to activities with lower risk and persistent underreporting of accidents may be linked to reductions found ${ }^{(8)}$.

The most economically developed Brazilian regions with the highest incidences of occupational accidents are the South and Southeast. If, on the one hand, economic development expands possibilities in the labor field, with an increase in the supply of employment, social insertion and a reduction of social inequality, on the other hand, it also entails a high cost, represented by injury to the health of the worker in the form of accidents ${ }^{(10)}$. Added to this factor, these regions can have a greater number of notifications of the accidents and therefore have a greater incidence.

The male worker suffers almost double the number of accidents when compared to female workers. This is not explained exclusively by the greater proportion of men in the labor market, but due to tasks associated with greater physical risk, the need for demonstration of courage and strength, which are cultural values traditionally attributed to men. Thus, one can perceive these cultural aspects related to the gender interfering in the occurrence of the work accidents ${ }^{(11)}$.

Regarding work-related accidents analyzed according to the age group, a higher incidence of 20 to 49 years was observed, confirming what has been described in the literature for this period of life of greater productivity and subjection to risks at work ${ }^{(12)}$.

The highest prevalence of accidents according to the causes was identified in the group of injuries, poisonings and some consequences of external causes such as fractures or injuries, reflecting the registry of cases that occur in the environment and working hours, so-called typical accidents, together with the accidents that occur on the way between the home and the workplace. Due to their circumstances, these cases are more difficult to underreport. Also due to this high incidence are the changes in the work processes, in which the work environments can be seen to be expanded, incorporating the streets as workplaces. 
Diseases of the musculoskeletal system, led by back pain, are also among the main causes of withdrawal from work. Back pain was the major cause of work-related accidents in this group of diseases (35\%), which is close to those indicated by European statistics, in which the complaint of low back pain affects $27 \%$ of workers, interfering with their quality of life ${ }^{(13)}$. These diseases are related to the physical structure of the workplace, raising the discussion of ergonomic aspects as the cause of work-related illnesses that are sometimes neglected ${ }^{(14)}$.

The third most common group of causes of accidents is that related to external causes of morbidity and mortality. Among them, the bite or blow caused by dogs was the most frequent and is probably related to the activities that must be performed with the need to visit the Brazilian households ${ }^{(15)}$.

Mental and behavioral disorders, although they express a small percentage when compared to the other groups, denounce the new aspects of work organization, in which workers are forced to perform more and more multiple tasks that result in mental illness ${ }^{(16)}$. Reactions to severe stress and adjustment disorders were more frequent in this group and may be related to the work environment, pointing to an increasingly hostile and responsible place to cause harm to workers and interfere with their quality of life ${ }^{(17)}$. Evidence of this type of illness caused by work must be taken into account in the discussion of mental health policies, above all for the prioritization of prevention and surveillance actions ${ }^{(18)}$.

Accidents related to factors influencing health status and contact with health services appear next, pointing to a greater concern with the notification of these types of accidents due to the risk of illness due to infectious diseases, since these workers are often exposed to biological materials ${ }^{(19)}$.

With regard to the analysis of the incidence of work accidents according to economic activities, there was a higher prevalence of accidents in the branch of the manufacturing industry that is responsible for the change of the raw material in utensils for man. These activities are predominantly located in the South and Southeast regions of Brazil, coinciding geographically with the largest number of accidents identified in this study. This result corroborates the idea that industrialization has brought about an important consequence for the developing countries in the risk of accidents at work ${ }^{(20)}$.

Accidents related to the production of raw sugar stood out in this branch of activity. In this sense, it can be said that the expansion of the sugar industry associated with the rhythm of exhaustive work increases the risk of accidents of workers linked to the transformation of sugarcane, who end up having a high rate of absenteeism ${ }^{(21-22)}$. Still in the processing industry, the activities related to the slaughter of pigs, poultry and other small animals show the poor working conditions to which the workers of the slaughterhouses are exposed. Intense work rhythms, as well as equipment without adequate ergonomic adjustments and high turnover contribute to a high number of accidents in these activities ${ }^{(23)}$.

When compared to the others, the branch of human activities and social services presented hospital care activities as the occupation with the highest frequency of accidents. In this sense, it is relevant to mention that human health activities may be related to accidents due to exposure to biological agents ${ }^{(16)}$. According to the literature, most of these accidents are related to injuries resulting from the manipulation of piercing-cutting materials, such as needles and ampoules, and pose a great risk to health professionals, especially nurses ${ }^{(24)}$.

The activities of the construction industry, especially the construction of buildings, reached the fourth place in the ranking of accidents in Brazil. High-income countries, such as Canada, have a $26 \%$ share of work-related deaths from construction. Studies point to the need to improve both physical safety and psychological aspects as a way of reducing these types of accidents among those surveyed in this study ${ }^{(25)}$.

\section{Limitations of the study}

The limitation of this study is the fact that it does not cover informal workers and only workers enrolled in Social Security are included. In addition, the Social Security database may have been hampered by the interference of underreporting of accidents. Even in view of this fact, the Social Security database has been used as a reference in several scientific studies.

\section{Contributions to the area of nursing, health or public policy}

Based on the results and the discussion presented, it can be said that, this study points to the need to improve public policies that contemplate preventive actions with a more refined look at each type of accident, that is, that take into account the differences identified according to the Brazilian regions, sex, age of workers, causes of accidents and the branch of economic activity involved.

In particular, accidents due to hospital care activities are mentioned, due to the greater frequency of accidents in this environment. Therefore, it is recommended to invest in the training of health/nursing professionals in order to comply with the established protocols, above all, for those involved in the manipulation of biological material resulting from health care and from sharp-cutting materials.

Despite the reduction of work accidents in Brazil, there are still challenges related to the issue. The persistence of underreporting, the lack of efficiency of policies with a preventive look and of acting for the surveillance of workers' health are obstacles to be overcome.

\section{CONCLUSIONS}

Work accidents decreased in Brazil, in their geographic regions, in the analyzed age groups, and in both sexes between the years 2008 and 2014. Despite this, attention is drawn to the high incidence of accidents. These were more frequent in the South and Southeast of Brazil, male, aged between 20 and 49 years, with a higher prevalence in the manufacturing industry and in the group of causes related to poisoning injuries and some other consequences of external causes, highlighting the accidents that affected the hands and wrists. In order to obtain greater reductions in work-related accidents, improvements are needed in relation to accident records and advances in policies that address prevention and surveillance of workers' health. 


\section{REFERENCES}

1. Lederer V, Rivard M. Compensation benefits in a population-based cohort of men and women on long-term disability after musculoskeletal injuries: costs, course, predictors. Occup Environ Med. 2014;71(11):772-9. doi: 10.1136/oemed-2014-102304

2. Ministério da Previdência Social (BR). Aeps. Base de dados históricos da Previdência Social [Internet]. 2014 [cited 2017 Oct 4]. Available from: http://www3.dataprev.gov.br/temp/DACT01 consulta32082337.htm

3. Malta DC, Stopa SR, Silva MMA, Szwarcwald CL, Franco MS, Santos FV, et al. Self-reported occupational accidents among Brazil's adult population based on data from the 2013 National Health Survey. Cienc Saude Colet. 2017; 22(1):169-78. doi: 10.1590/1413-81232017221.17862015

4. Andrade SSCA, Jorge MHPM. Hospitalization due to road traffic injuries in Brazil, 2013: hospital stay and costs. Epidemiol Serv Saude. 2017; 26(1):31-8. doi: 10.5123/s1679-49742017000100004

5. Lima RKS. Fatores associados à notificação de acidente de trabalho em unidades sentinela em saúde do trabalhador no município de Fortaleza, Nordeste do Brasil [Internet]. [Dissertação]. Ceará: Universidade Federal do Ceará, Faculdade de Medicina; 2017 [cited 2019 Apr 16]. 70 p. Available from: http://www.repositorio.ufc.br/handle/riufc/22848

6. Pina JA, Stotz EN. [Work intensification and workers' health: a theoretical approach]. Rev Bras Saude Ocup. 2014; 39(130). doi: 10.1590/03037657000074913 Portuguese.

7. Ministério da Previdência Social (BR). Instituto Nacional de Seguro Social. Empresa de Tecnologia e Informações da Previdência Social. Anuário Estatístico da Previdência Social. Suplemento histórico (1980-2014) [Internet]. Brasília: MPS/DATAPREV; 2014 [cited 2018 Aug 16]. Available from: http://www.previdencia.gov.br/wp-content/uploads/2016/08/aeps2014_suplemento.pdf

8. Almeida FS, Morrone LC, Ribeiro KB. [Trends in incidence and mortality due to occupational accidents in Brazil, 1998-2008]. Cad Saude Publica. 2014;30(9):1957-64. doi: 10.1590/0102-311X00009213 Portuguese.

9. Ministério da Fazenda (BR). Secretaria de Previdência. Anuário Estatístico da Previdência Social [Internet]. Empresa de Tecnologia e Informações da Previdência. Brasília: MF/DATAPREV, 2015 [cited 2017 Oct 4]. Available from: http://sa.previdencia.gov.br/site/2015/08/AEPS 2015-FINAL.pdf Portuguese.

10. Vargas F. O mercado de trabalho e a questão do emprego no Brasil: integração precária e desenvolvimento desigual. Rev Bras Sociol. 2014; 2(4):183-204. doi: 10.20336/rbs.82

11. Stergiou-Kita M, Mansfield E, Bezo R, Colantonio A, Garritano E, Lafrance M, et al. Danger zone: Men, masculinity and occupational health and safety in high risk occupations. Saf Sci. 2015; 80:213-20. doi: 10.1016/j.ssci.2015.07.029

12. Scussiato LA, Sarquis LMM, Kirchhof ALC, Kalinke LP. [Epidemiological profile of serious accidents at work in the State of Paraná, Brazil, 20072010]. Epidemiol Serv Saude. 2013;22(4):621-30. doi: 10.5123/S1679-49742013000400008 Portuguese.

13. Santos KOB, Almeida MMC, Gazerdin DDS. Back pain and work-related functional disabilities: records from the Notifiable Diseases Information System (SINAN/DATASUS). Rev Bras Saude Ocup. 2016; 41(0):e3. doi: 10.1590/2317-6369000116915

14. Sousa-Uva A, Serranheira F. [Work and health/disease: the continuous challenge of occupational risk prevention and the recurrent forget fullness of health promotion]. Rev Bras Med Trab [Internet]. 2013 [cited 2019 Apr 16];11(1):43-9. Available from: https://www.anamt.org.br/ site/upload_arquivos/revista_brasileira_de_medicina_do_trabalho_volume_11_n\%C2\%BA_1_111220131711187055475.pdf Portuguese.

15. Mascarenhas FAN, Barbosa-Branco A. [Work-related disability among postal employees: incidence, duration, and social security costs in 2008]. Cad Saude Publica. 2014;30(6):1315-26. doi: 10.1590/0102-311X00166512 Portuguese.

16. Cordeiro TMSC, Mattos AIS, Cardoso MDCB, Santos KOB, Araújo TMD. [Reporting of work-related mental disorders among workers in Bahia: a descriptive study, 2007-2012]. Epidemiol Serv Saude. 2016;25(2):363-72. doi: 10.5123/s1679-49742016000200015 Portuguese.

17. Schaefer LS, Lobo BOM, Kristensen CH. [Posttraumatic stress disorder resulting from occupational accident: psychological, socioeconomic, and legal implications]. Estud Psicol (Natal). 2012;17(2):329-36. doi: 10.1590/S1413-294X2012000200018 Portuguese.

18. Silva Jr JS, Fischer FM. Disability due to mental illness: social security benefits in Brazil 2008-2011. Rev Saude Publica. 2014;48(1):186-90. doi: 10.1590/S0034-8910.2014048004802

19. Oliveira A, Paiva MH. Analysis of occupational accidents with biological material among professionals in pre-hospital services. Rev LatinoAm Enferm. 2013;21(1):309-15. doi: 10.1590/S0104-11692013000100004

20. Hatami SE, Ravandi MRG, Hatami ST, Khanjani N. Epidemiology of work-related injuries among insured construction workers in Iran. Electron Physician. 2017;9(11):5841-47. doi: 10.19082/5841

21. Pinto JM. [Trend in the incidence of accidents and work-related diseases in Brazil: application of the Hodrick-Prescott]. Rev Bras Saude Ocup. 2017;42:1-12. doi: 10.1590/2317-6369000003016 Portuguese.

22. Ceccato ADF, Carvalho Jr LCS, Cuissi RC, Monteschi M, Oliveira NG, Padovani CR et al. [Absenteeism due to occupational diseases among sugarcane workers]. Cad Saude Publica. 2014;30(10):2169-76. doi: 10.1590/0102-311X00026413 Portuguese.

23. Simonelli AP, Jackson Filho JM, Vilela RAG, Almeida IM. [Influence of behavioral safety practices and models of prevention of occupational accidents: a systematic review of the literature]. Saude Soc. 2016;25(2):463-78. doi: 10.1590/S0104-12902016147495 Portuguese. 
24. Elseviers MM, Arias-Guillén M, Gorke A, Arens HJ. Sharps injuries amongst healthcare workers: review of incidence, transmissions and costs. J Ren Care. 2014; 40(3):150-6. doi: 10.1111/jorc.12050

25. Chen Y, McCabe B, Hyatt D. Impact of individual resilience and safety climate on safety performance and psychological stress of construction workers: a case study of the Ontario construction industry. J Safety Res. 2017; 61:167-76. doi: 10.1016/j.jsr.2017.02.014 